\title{
Fetus Trafficking in Viet Nam - The New Criminal Method of Human Trafficking
}

\author{
Ha Le Thuy ${ }^{1, *}$, Hoang Thi Hai Yen ${ }^{1}$ and Nguyen Quang Bao ${ }^{2}$ \\ ${ }^{1}$ Doctor of Law at University of Law Hue, Viet Nam \\ ${ }^{2}$ Master at People's Security Academy, Viet Nam
}

\begin{abstract}
When it comes to basic rights of the fetus, including the right to life, theoretical studies around the world on human rights of the fetus still have not reached an agreement on approaches and explanation. Criminal law at the international and national levels still leaves the possibility of protecting the unborn child. Viet Nam's criminal law is no exception to this trend. In addition, Viet Nam is currently facing human trafficking with new methods and tricks. Children are bought and paid for while still in the womb, then born abroad and given to traffickers. Children are only protected by criminal law for human trafficking if they are born, alive, and detected by the authorities. While the act of trafficking in fetuses is often easily detected by the authorities right from the stage of purchasing and paying, it is not feasible to prosecute this act for human trafficking under the criminal law of Viet Nam. This reduces the criminal law's ability to suppress crime, at the same time, leaves many fetuses unprotected. Should criminal law be left outside the legal mechanism to protect children while in the fetal stage? This article suggests considering fetus trafficking as a form of human trafficking and to criminalize fetus trafficking. Criminal law should recognize fetus trafficking as a sign of crime or an early stage in the criminal process of human trafficking, because children need special care and protection, including appropriate legal protection before and after birth, due to their physical and mental immaturity.
\end{abstract}

Keywords: Fetus trafficking, human trafficking, fetus's right, Viet Nam, criminology, the new method, criminal law.

\section{INTRODUCTION}

Human trafficking is a transnational crime. It has become a global problem plaguing numerous countries, including Viet Nam. At the beginning of the twenty-first century, human trafficking will still be a topical issue that cannot be avoided anywhere in the world (Parisot, 2002). As a complicated phenomenon, human trafficking includes many different types of criminal activities (Pryimachenko et al., 2021). Among them is the use of embryos or fetuses for any gain. Alternatively, it can be trafficking in persons for illegal removal of their organs (Levchenko et al., 2011). This action threatens the non-traditional security, which is a burning topic on the agendas of countries when it comes to international cooperation in the fight against crime. Up to now, there is no international legal document that provides a definition of fetus trafficking, but through the definitions of human trafficking and children trafficking, it can be understood that fetus trafficking is also a method of children trafficking for various purposes. However, it is difficult to know the future of a new born child after the successful transaction between the pregnant woman and the criminal. There is no research to shed light on this issue, but a new born child seem to be sold to a third person who wants to have a child for adoption, or for inhumane purposes and organ trade. These purposes

*Address correspondence to this author at the Lecturer of University of Law Hue, Viet Nam; E-mail: thuyhl@hul.edu.vn show the nature and danger of fetus trafficking. It is believed that fetus trafficking is a new method of human trafficking, which should be understood as the use of money, property or other material benefits to buy and sell fetuses for illegal purposes. Such behavior can be carried out by means of the threat or use of force or other forms of coercion, of abduction, of fraud, of deception, of the abuse of power or of a position of vulnerability or of the giving or receiving of payments or benefits to achieve the consent of a pregnant mother.

Meanwhile, research into new tricks and methods of human trafficking, especially fetus trafficking in Viet Nam, is still limited. Therefore, this study is necessary to explore another aspect of human trafficking in Viet Nam. This study aims to answer the questions of whether fetus trafficking is a trend for human traffickers, if Vietnamese law have a mechanism to punish this behavior, and how to do this. Besides, what Viet Nam should do to limit and prevent criminal acts of human trafficking in the time to come is also discussed.

\section{LITERATURE REVIEW}

As a form of human trafficking, fetus trafficking has also drawn the attention of multiple scholars. In the world, there have been a number of works on this issue. When studying the latest aspects of international cooperation in the fight against transnational trafficking, the authors of the article (Chornous et al., 2020) determined that, fetus trafficking is considered one of 10 human trafficking crimes according to international 
law. It is also stated that transnational human trafficking cannot be stopped without international cooperation between states, their agencies, international organizations. According to a study by Huntley (Huntley, 2013), the roots of fetus trafficking are poverty, high unemployment rate, especially in rural areas, low levels of education and training, corruption, and a lack of information concerning smugglers. Regarding forms of crime, Huntley pointed to a Nigerian "baby factory" disguised as a maternity home, an orphanage, a house of social welfare and a clinic. To be more specific, when teenagers or women with unintended pregnancies visit doctors, clinics, nurses, and orphanages, they are taken care of. However, when the children are born, they will be sold to those in need. To legalize the purchase, traffickers asked the mother to sign a document denying her child and agreeing to receive compensation. Traffickers often lure those women and children, who are vulnerable to social stigma, with false promises of employment or safe abortion. Traffickers contain them in one place and control them until the child is born and sold to a third party. Meanwhile, another group of authors (Nguyen et al., 2020) state that human trafficking is among the most serious problems in many Southeast Asian countries, including Viet Nam. Victims of these crimes are not only children and women, not least pregnant women, but also men, who are trafficked for a variety of purposes.

Furthermore, according to Zimmerman (Zimmerman et al. 2003), victims of human trafficking often suffer a lot mentally, physically, and sexually. Even when victims escape the criminals, they face many risks in rehabilitation. Recently, trafficking organs and embryos has become a new trend of human trafficking criminals. To some poor women, their unwanted pregnancies can place a burden on the family. Understanding the situation, perpetrators lured these women to give or sell the baby after birth for adoption (Nguyen et al., 2020). Among forms of human trafficking, fetus trafficking is a new, extremely dangerous practice. In Viet Nam, fetus trafficking is considered a new variant of human trafficking. The practice adversely affected the morality, lifestyle, fine customs, and traditions of Vietnamese people, tarnished the sacred motherhood, and brought about many serious consequences to the society. It is very difficult to identify the practice. Children have their fates decided from the moment they are in their mothers' womb, or even before they exist in any form, and there is no guarantee that these children will be raised by families with no children or brought elsewhere.

\section{RESEARCH METHODOLOGY}

From a human right perspective, the main purpose of this article is to clarify the rights of fetuses and explain why it is necessary to consider the act of fetus trafficking a method of human trafficking. At the same time, through assessing the status of fetus trafficking in Viet Nam as well as pointing out the tricks of criminals, the article also examines the factors causing fetus trafficking. The article also assesses the current legislation regulating fetus trafficking at the international and national level and the legal barriers that make it difficult to deal with fetus trafficking.

In addition, the article is made based on the review and analysis of existing documents and reports in the field of research. Statistics from the Ministry of Public Security and courts on cases brought to trial related to fetus trafficking are also used for analysis, assessment, and synthesis. The research result also gives an insight into laws related to the protection of fetus rights and handling fetus trafficking. On that basis, the article also offers suggestions to improve Viet Nam's law and prevent fetus trafficking in particular and human trafficking in general.

\section{FETUS'S RIGHT}

Regarding an unborn child's human rights, there are many different approaches and explanations in the world to protect the rights of the unborn child. From a philosophical, ethical, or biological perspective, most of the views show the appropriateness and necessity to consider the fetus a living entity with a certain age, though it does not exist socially. At the same time, after being born, this living entity is the first stage to confirm the existence of a person. The medical field appreciates haptonomy, as a fetus in the mother's womb can still communicate, hear and feel the outside sounds, actions, words, and even emotions from the mother when the fetus develops to a certain stage (usually on the fifth or sixth month of pregnancy), which means the unborn child's right to life is acknowledged.

So is the fetus really a human or just an object with consciousness? Does it exist independently or is it a part of a pregnant woman's body? In one of his articles, Warren Murray affirms that fetus also needs recognizing the existence and giving certain rights and therefore, it is necessary to ensure the rights of the fetus (Murray, 1989). The article relies on biological, ethical, and philosophical factors to justify that a fetus's rights are a part of human rights. The author argues 
that a fetus is an existing and individual being, although it is not yet complete.

The extraordinary development in genetics, embryology, and fetal medicine shows that the fetus is a part of the continuous and comprehensive development of the human being. A fetus has structured organs and some of its activities reveal its awareness, sensitivity to its environment, and ability to learn, even before it is born. For example, it is known that babies learn to recognize their mother's voice before they are born. Their neurons also have a number of networks, which form a pre-learning process for some distinct human behavior, such as speaking and bipedal walking.

A fetus is a body outside its mother's body, but in a very natural relationship with its mother, the fetus is dependent on the mother. It does not mean that the fetus is a part of the mother's body, instead it is a parasite on the mother's body to survive when not yet capable of living outside. Thus, the fetus still has rights corresponding to the stages of development as a human being. However, these rights only contain to health and property. It can be born as an heir, even if it cannot yet exercise this right in any way. The right to life is emphasized: "A fetus has not only the right to life, but also the right to know it. Thanks for studies in embryology, it has the right to be considered a patient like his mother. Thus, it is entitled to care that ensures its health and normal development, according to the advancement of medicine, the availability of such care and the resources of the society" (Murray, 1989).

It is essential that the rights of both a fetus and its mother be fully and equally respected. In certain cases, some women's rights, such as smoking, drinking alcohol, or taking certain drugs need to be considered in line with the development of the fetus. If the fetus's life is affected, it should be limited and prevented. Accordingly, an author analyzes the case of a pregnant woman who used stimulants, which affected the fetus, and was taken to court to assess impact on the fetus (Harris, et al., 2003). The author points out that prosecutors considered a living fetus a child and argued that a pregnant woman's drug use or addiction is the abuse to the child. Or even in all murders, prosecutors considered a living fetus a child and argued that existing murder laws should be applied to women's actions. Only the superior court of South Carolina reached a different conclusion, interpreting the word "child", in the criminal statutes of danger to children, to include living fetuses. In doing so, the court applied child danger status to pregnant women whose actions pose a risk to the fetus, and set a precedent for the application of other criminal laws of South Carolina on pregnant women.

On the contrary, the majority believe that a fetus should not be consider a child. It is reflected in the fact that courts have refused to extend existing state law to punish pregnant women based on fetal rights claims (Chornous et al., 2020). Judges state that the plain meaning of "children" does not include the fetus, the terms "parent" or "guardian" do not include a pregnant woman in relation to the fetus, and the word "birth" does not include the delivery of drugs, through the umbilical cord circulation. The admission and application on pregnant women in cases of drug use would violate the principles of constitutional procedure. It could lead to prosecution of other cases, from smoking, giving birth in the old age, to working in a potentially dangerous job. Such an amendment to the law may inadvertently encourage harbingers of abortion or avoidance of prenatal care or addiction treatment. Although the author of the article provide evidence to affirm that, in the United States, there is places that recognize fetal life and protect the rights of the fetus through punishing pregnant women who commit acts affecting the fetuses. However, this course of action has not yet been recognized throughout the territory by not advocating criminal prosecution against pregnant women for prenatal actions.

From a legal perspective, the rights of the fetus are also discussed to answer the question of when the human right to life begins. This question is related to the long-standing controversy over the rights of the fetus as well as the legality of abortion. This leads to two points of view: the pro-abortion stance does not recognize the fetus's right to life, while the non-abortion one acknowledges the fetus's right to life.

Allowing abortion means a fetus does not have the full quality of a human being, so the pregnant woman still retains the freedom to do anything with their bodies. In 2005, in the case of Thi Nho Vo against the French Government, the plaintiff was a FrenchVietnamese woman who was forced to the verge of abortion (Plomer, 2005). Initially, the defendant was found guilty of manslaughter, but the French Court of Appeal overturned the sentence and declared that "the unborn child is not considered a "human" protected by the criminal law". Subsequently, the European Court of Human Rights reaffirmed that Article 2 of the European Convention on the Right to Life does not protect the 
unborn child and that, if a state recognizes the unborn child's right to life, this right is limited by the rights of the pregnant mother. Similar arguments are also found in the judgments and comments of international human rights agencies regarding the state's prevention of abortion. Accordingly, these agencies recommend that the countries abolish criminal penalties for women who perform abortions, and it is necessary to regulate this activity to take place in certain cases, for example in the case of a woman being raped, incestuous. In 1981, the Inter-American Council on Human Rights in the "Baby boy case" further clarified that the exceptions to abortion were "for the purpose of saving the life of the mother and in the case of rape" (De Jesus, 2011). In his article (Duc, 2021), the author argues that the prohibition on abortion does not mean that the law recognizes the right to life of the fetus. These regulations are intended to protect the health of pregnant women and balance with other public goals of the state. The author also analyzes and evaluates the provisions of international law and argues that: international law, including the Convention, does not have specific provisions on fetal rights. Therefore, countries have the right to decide this issue for themselves based on the moral, cultural, religious values and circumstances of each country.

Meanwhile, the opposite view is that the fetus should be considered as a child, therefore abortion is an immoral act that infringes on human rights to life. Therefore, there are some countries that prevent or even criminalize this activity. According to an article (Udasmoro, 2003), legalizing the act of abortion has risks of infringing upon the right to life of the fetus. Legalization of abortion in Indonesia is only allowed when there are two signs - a medical emergency and the victim is raped. In Indonesia, the reproductive rights of women and the fetus's right to life are regulated and protected by the legal system. While the right to reproductive health protection is regulated by Indonesian law through reproductive health services including legal abortion for the safety of a woman's life and health, the state also deeply concerns about the fetus's right to life. Indonesia's 1945 Constitution stipulates that everyone has the right to live and defend their own life, every child has the right to exist, grow up, develop, and to be protected from violence and discrimination. The government respects women's reproductive rights, but the government also respects the right to live in the womb. There is no sentence in the Indonesian legal system that considers a woman's reproductive rights more important than the right to life of the fetus and vice versa. These two rights are equally important. Abortion is illegal if it is performed illegally - incompetent and with rudimentary standards and infrastructure, often carried out in secret and fraught with risk. Another author (Tran, 2017) said that abortion violates two fundamental rights of human rights, those are, the fetus's right to life and the equal right of women. Therefore, to protect the rights of the fetus, the act of illegal abortion should be criminalized and should be placed in the chapter "crimes against human life" because its nature is to deprive the individual's opportunity to live. The article approaches from the perspective of a comparative study of the criminal law of Viet Nam with the Federal Republic of Germany on preventing abortion for gender reasons by criminal law in order to protect the rights of the fetus.

Starting from the practical legal perspective, the theoretical perspective on human rights, and on the basis of the above points of view, the authors of this article support the view that the fetus has certain rights that need to be protected. It also means that abortion is considered an infringement of human rights. Therefore, abortion can only be performed if there is a risk to the mother's health and/or the abortion is performed at the time when the gender of the fetus is not known in order to eliminate the abortion for gender. More importantly, the authors believe that protecting and recognizing the rights of the fetus will partly prevent fetal trafficking - a new trick of human trafficking, which needs to be dealt with immediately at the time of discovery, not until the child is born.

\section{THE CURRENT SITUATION OF FETUS TRAFFICKING IN VIET NAM}

Virtually no country appears to be immune to human trafficking, regardless of its particular economic, political, or social conditions (Winterdyk et al., 2010). Viet Nam is a country that shares borders with countries in Asia including China, Laos, Cambodia, and has a coastline stretching across the country. Therefore, this is an extremely favorable condition for the commission of transnational crimes as criminals can easily bring victims across national borders.

According to a report of the Governmental Steering Committee 138 on crime prevention and control, there were 74 cases were detected nationwide in the first six months of 2020, involving 104 traffickers and 98 victims. Compared with the same period in 2019, there is a decrease of $16.85 \%$ in the number of cases, $26.76 \%$ in the number of subjects, and $42.01 \%$ in the 
number of victims. The commercialization of surrogacy for foreigners or unplanned pregnancies is a current noteworthy situation. The functional forces have received and handled promptly hundreds of messages. Police and Border Guard forces discovered 61 cases and arrested 79 people. People's Procuracy at all levels prosecuted 34 cases with 51 defendants. The People's Courts at all levels handled 57 cases with 92 defendants committing crimes of human trafficking, 52 out of these 57 defendants were sentenced to fixedterm imprisonment, of which 1 defendant was sentenced to prison for over 15 years, 24 defendants were sentenced to prison from 7 to 15 years, 23 defendants sentenced to 3 to 7 years imprisonment. Based on the Final report on the National Plan of Action against Human Trafficking, period 2011-2015 of Viet Nam (No.439/BC-BCD), the majority (70\%) of human trafficking cases occur at the Viet Nam-China border, mainly in Quang Ninh, Lang Son, Cao Bang, Lao Cai, and $\mathrm{Ha}$ Giang provinces. 10\% of human trafficking cases occur at the Viet Nam-Cambodia border, mainly Tay Ninh, An Giang, Dong Thap, Hau Giang, and Kien Giang provinces. $6 \%$ of the cases occur in the Viet Nam-Laos border, mainly in Thanh Hoa, Nghe An, Ha Tinh, and Quang Tri provinces.

Fetus trafficking is a recently established criminal behavior of human trafficking. This unprecedented behavior is considered extremely dangerous. Through research on the current situation of fetus trafficking in Viet Nam, the authors found that this kind of trafficking mainly takes place in border areas of the northern mountainous provinces. After concluding the trade deal, the majority of pregnant women were brought to China to give birth and complete the trade deal in China. The main criminal methods of traffickers include:

- Taking advantage of a humanitarian veil of looking for children for adoption.

Traffickers often come to the adoption association to search for pregnant women who are disadvantaged and intend to give away their children after giving birth. The traffickers then convince such women to give their children and receive a compensation of 70 to 100 million VND (Lien lien, 2019). In order to be trusted by pregnant mothers, the criminals are also willing to publicize their identity cards, passports, and even home addresses. The requirement is that traffickers will take care of all the formalities for the women to go to China to give birth. Afterward, the mothers will return to their home countries while their newborns will be left in
China. Whether the newborn was adopted by someone else is still a question, but the traffickers explained that it was necessary to send women to another country to give birth to avoid the control of the functional agencies.

- Taking advantage of the difficult and dire

Criminals seek to get acquainted with women whose wives or "eating first" lead to pregnancy, do not want to raise children in order to tempt them to sell their newborn babies or make a deposit from the time the mother is pregnant. The birth will receive the child and hand over the money as agreed. Typically, the case of Ms. Nguyen Thi Ut, 34 years old woman, residing in Bac Lieu province, was 8 months pregnant at that time. Ut was abandoned by her husband, depressed, and did not want to have children, but the fetus has grown and cannot be aborted. Grasping this weakness, the couple Hien and Hoa lured her to Hanoi, sold the fetus, and paid a deposit until the child was born. With the price of 8 million VND, the two subjects waited until the day Ut gave birth to a baby boy to carry out their intention to sell abroad for profit (Dang Truong, 2008). Recently, the subjects also used tricks to join social networking sites to entice women who "missed the village" to have children, so there is a need through social networking sites to search for "infertile" families, infertility" need to adopt. These subjects will talk and entice these women to raise babies to sell to the Chinese (Minh Tam, 2020).

Taking advantage of the gullibility and poor perception not only of the law but also of morality of pregnant women, especially ethnic minorities.

The majority of fetus trafficking cases take place in mountainous, remote, and underdeveloped areas with many difficulties in transportation and the victims are ethnic minority women. The jobs of the victims before being tricked into being sold abroad were mainly farming or unemployed. The victims did not have enough social information, and their educational attainment was low. According to an article (Tien Hoang Le, 2018), ethnic minorities, people of low education level or people living in remote areas in mountainous or rural areas have little opportunity to access information on trade. as well as limited understanding of human trafficking. Therefore, they are easily taken advantage of and believe criminals, becoming victims of fetus trafficking. 
In addition, the subjects often hit on the "fear of being punished for giving birth to a third child" mentality of pregnant women here to entice them to raise the fetus to sell their newborns to China. A typical example of cross-border embryo trafficking is the case in Ky Son district, Nghe An province. According to the local review, there were about 30 cases of pregnant ethnic minority women coming to China to give birth. Many of them admitted that due to difficult circumstances, they went to China to give birth and then sell their children, despite knowing this action is against the law and morality (Thien Thanh, 2019).

\section{- Taking advantage of financial difficulties}

Criminals convince people who are in economic difficulty, unemployed, and have no income to convince them to get pregnant and sell their newborn. According to $(\mathrm{Vu}, 2017)$, due to lack of working opportunities, no income or low income causes people to migrate to the border for human trafficking, including trafficking newborns to have higher income. With the money received after each child sale is usually from 40 to 80 million VND (the price of a boy is higher than the price of a girl), women who sell their children while they are still fetuses will use the money to buy household items such as: motorcycle, or repair houses, cover economic difficulties such as repaying bank loans (Quoc Nam et al., 2020). Pregnant women even actively seek out brokers to sell their children while they are still in the womb. Some have sold up to two of their children, with the consent of their husbands (Khanh Hoan, 2018). When the due date is near, these pregnant women will be illegally taken to China to give birth and then return alone.
- $\quad$ Taking advantage of the form of traveling or working in neighbor countries.

The subjects not only lured pregnant women to the border to give birth and then hand over the children, they also seduce and seduce the husbands of the pregnant women to trick both victims. people to China legally for tourism purposes, or to work as workers. Typically, in the case of Huu Kiem, Ky Son, Nghe An communes, the commune police have learned that there are a number of Kho Mu couples taking each other since the beginning of 2020 , with the declaration that they went to China to work, but they did not know that they were working. In fact, they got pregnant there, gave birth and sold it, and then came back. Another new form also arose where some Kho Mu women were brought to China under "contract" as wives. After giving birth, they will be "released" along with an amount of compensation (Quoc Nam et al., 2020).

According to the local agency, traffickers usually do not reside in Viet Nam but they communicate and direct from ChinaThere are also many traffickers who are local people, have now moved to China and earn a living there (Nguyen Thao, 2019). Currently, the human trafficking network is becoming increasingly sophisticated. The traffickers use the victims, who are tricked into being sold to China and through the process of living there, married the Chinese local men. The women who used to be the victims of the traffickers are recruited into the fetal trafficking network to return to Viet Nam and trick friends and relatives who are pregnant women in the countryside (Quoc Nam et al., 2020).

There are other cases discovered when the traffickers were on their way to bring pregnant Vietnamese women to China to sell their children through minor roads. These cases are usually treated as crime of "illegal smuggling cross the border" in Article 349 of the Penal Code 2015. One typical case is the case of Police Investigation Agency of Quy Hop district, Nghe An province discovering and rescuing 3 pregnant women who were about to go abroad to sell their fetuses. The three pregnant women reported that they were brought to China by a trafficker to sell the fetus to the Chinese for 30 million VND for female fetuses and 70 million VND for male fetuses. However, This behavior was quickly detected and prevented by $\mathrm{H}$. Quy Hop Police. At the time it was discovered that these three women were "growing the fetus", from 3 months to 7 months old, preparing to sell their children to the Chinese for money (Minh Tam, 2020).

\section{LEGAL FRAMEWORK}

Human trafficking violates the basic human rights. To combat this criminal activity, the international community has developed a document designed to provide effective legal provisions for the fight against human trafficking - the Prevention, Suppression and Prevention Protocol of human trafficking, especially women and children (Pryimachenko et al., 2021). Viet Nam has also specify the ideas set forth in the Protocol in the form of an effective system of measures to combat human trafficking at a national level. Specifically, Viet Nam has ratified or jointed most of the important international instruments to combat human trafficking and protect women and children such as: United Nations Convention against Transnational 
Organized Crime (TOC), ASEAN Convention against Human trafficking, especially in Women and Children, Protocol on the Prevention and Punishment of Human trafficking, especially Women and Children, to supplement the TOC Convention. Viet Nam also participates in the Global Agreement on Legal, Safe and Orderly Migration - the first intergovernmental agreement on migration, and has issued a plan to implement this agreement, with specific solutions. In bilateral cooperation, Viet Nam continues to effectively implement cooperation agreements between Viet Nam and Cambodia, Laos, Thailand, China, and the UK on human trafficking prevention and combat, including maintaining annual meetings with the agency implementing the agreement, coordinating to organize the peak waves to attack and suppress the crime of human trafficking. Viet $\mathrm{Nam}$ is also implementing cooperation projects within the framework of the ASEAN-ACT Program sponsored by the Australian Government. In addition, Viet Nam regularly discusses its policies and achievements in combating human trafficking at the Human Rights Dialogue with the EU, Australia as well as regular meetings with a number of representative agencies.

At the domestic level, Viet $\mathrm{Nam}$ has issued regulations related to the fight against crimes and violations of the law, and other regulations to protect the rights of the fetus. Among them are the Law on Prevention of Human trafficking 2011, the provisions of the Criminal Code 2015, the Civil Code 2015. The provisions in these documents are the indirect legal basis to recognize the human rights of fetuses. There are the provisions in the Civil Code 2015 on the recognition of the right to alimony (Point a, Clause 2, Article 593) or the right to inherit inheritance of the fetus (Clause 1, Article 660), the Penal Code In 2015, many regulations in Article 36, Article 40, Article 51, Article 52, Article 67 to protect the interests of unborn fetuses from the risks of abusement, and at the same time increase penalty frame and determination of aggravating circumstances for cases of abuse against pregnant women.

It can be seen in the regulations not to apply community service labor measures to pregnant women or nursing children under 06 months old in Clause 4 Article 36; stipulates not to apply the death penalty or not to execute the death sentence for pregnant women and women who are raising children under 36 months of age in Clauses 2 and 3 of Article 40. For pregnant women commit the crime, pregnancy is considered an extenuating circumstance for penal liability at Point $n$,
Clause 1, Article 51. Besides, if the crime is committed against a pregnant woman, it is considered an aggravating circumstance at Point i, Clause 1, Article 52. Killing a pregnant woman is also considered an aggravating circumstance of the crime of murder specified in Point c, Clause 1, Article 123 of the Penal Code 2015. Decree No. 114/2006/NDCP on October 3 2006 of the Government's Regulation on sanctioning of administrative violations on population and children also punish intended abortion acts for the reason of sex selection.

\section{LEGAL BARRIERS}

The prologue of the 1989 Convention on the Rights of the child states that children, because of their physical and mental immaturity, need special care and protection, including proper legal protection, before and after their birth. However, this content has not been included in the content of the Convention. Perhaps the recognition of the right to life of the unborn child in the International Convention on the Rights of the Child is difficult because of disagreements over moral or religious values (Duc, 2021). By only noting in the preamble, they seem harmonize opposing views in order to create room for states to decide on their own, rather than make it compulsory (Alston, 1990). Accordingly, right before their birth, children should be provided with special protection of human rights, including inherent rights and most importantly, the right to life. Of course, in practice, there are cases where the right to life of the fetus must be considered regarding medical or humanitarian problems.

Currently, Viet Nam, like other countries in the world, does not legally recognize the right to life of the unborn baby. Although there are regulations that indirectly recognize the rights of a fetus as a human being as described in the legal framework, up to now, there have been no official regulations directly protecting the rights of the fetus against fetus trafficking. Thus, Vietnamese legal regulations have inconsistent points on this issue. The legal basis for not recognizing the right to life of the fetus is not to consider illegal abortion is an act of murder, but only criminal punishment for illegal abortion according to article 316-PC 2015. It is the highest legal document of legal obligations for illegal abortion, but it can be clearly seen that the criminal liability only applies when the act "causes damage to life, causes serious damage to the health of that person or has been disciplined, administratively sanctioned or the person has been sentenced for this crime, has not yet been remitted but 
continues to commit it". Thus, the subject of the regulation here is the person who performed an illegal abortion and pregnant person, not the fetus itself. Besides, the decision No. 4620/QD-BYT on November 25, 2009 of the Ministry of Health on the promulgation of "National Guidelines for Reproductive Health Care Services" states: "Abortion is the active use of different methods of termination of pregnancy in utero until the end of 22 weeks of gestation". This guideline of the Ministry of Health also implicitly acknowledges the possibility of abortion under 22 weeks.

In addition, the current Criminal Law includes up to 5 crimes related to human trafficking: Human trafficking (Article 150), trafficking of children under the age of 16 (Article 151), switching baby under the age of 1 (Article 152), appropriating children under the age of 16 (Article 153); buying and selling, appropriating human tissues or body parts (Article 154) but there is no crime related to fetal tissue trade. Therefore, discovered cases of fetus trade will only be prosecuted for the crime of organizing people to flee abroad (Article 349) or Crime of organizing surrogacy for commercial purposes (Article 187). Because there is no precedent, the investigation and trial of those crimes face many difficulties. Moreover, this practice has not been recognized and analyzed thoroughly in the ethical and legal aspects. Although the practice of negotiation of the organizer of crime is started and takes place while the mother is still pregnant, only when the organizer receives the child and hands over all the money (usually after giving birth), then the crime is completed. If the case is discovered and handled at this time (after the child is born), the law enforcement agency will still have enough basic grounds to prosecute for the crime of trafficking of children under the age of 16 (Article 151). However, in practice, doing this is extremely difficult. Because the organizers often take the pregnant mother abroad, hide them in secret places, even arrange people to watch and guard. After birth, a child can be quickly and secretly relocated. Therefore, even though the law reinforcement forces have implemented good international cooperation, it is still very difficult to track, detect, and catch them by the time the mother has given birth to the child in order to have a basis for prosecution. But if the action is caught red-handed before the child is born, the problem can not be solved due to the gap in the law. Thus, there will be an unreasonable circumstance, because with the same dangerous behavior, just due to the different time of detection and arrest (before and after the birth of the child) will lead to completely opposite results: is it a crime or does it not violate any regulations?
Currently, Viet Nam has signed bilateral and multilateral agreements with countries on extradition and mutual legal assistance, of which 23 are in force, 2 are in pending ratification and 5 are waiting for official signing. However, because the aim of the offender is not only to illegally transport and traffick people across the border of Viet Nam's neighbor countries, but also to transport victims through a second country (a country that shares a border with Vietnam) and then transfer the victim to a third country in need. Therefore, without a strong international cooperation mechanism with other countries, it is difficult to deal with human trafficking to the end. Especially when criminals have smuggled victims out of the border or smuggled into other countries, where there are traces and evidence that need to be collected and clarified in order to have sufficient grounds to detect the act of crime.

On the basis of international law and Vietnamese law, it can be seen that there are still legal obstacles and barriers to prosecute a person for fetal trafficking. First, from an international legal perspective, in the convention against human trafficking, it is recommended that countries can deal with child trafficking without necessarily having an exploitation basis, which is a mandatory sign. However, it is necessary to prove that there is an intention to exploit the victim, and it is only necessary to prove that there is an "act" such as recruiting, transporting, or receiving with the "purpose" of exploitation the victim. This point makes it difficult to handle fetus trafficking because of two reasons. First, that the criminal's purpose is to exploit the victim after the child is born must be proven. Second, the criminal will hide under the name of adoption or fake marriage to adopt a child after birth. In addition, if it is directly stated that fetus trafficking is a crime, it is almost impossible to prove the crime in fact because the motive, "for the purpose of obtaining organs or for other inhumane purposes" is obligatory sign of the crime but it is very difficult to prove. We can overcome that difficulty by stipulating that all acts of fetus trafficking, regardless of purpose, are illegal. However, this stipulation is in conflict with human rights and the concept of human being as a protected object of criminal law.

\section{CONCLUSIONS AND RECOMMENDATIONS}

The aim of fetal trafficking is the same with one of human trafficking, that is waiting until the child is born (Huntley, 2013). Although there are no statistics or descriptions about the purposes of fetal trafficking, one thing is for sure, criminals don't simply trade in fetuses, 
but they buy and sell babies in the womb. Therefore, it is necessary to protect a fetus from being trafficked after it is born. The recognition of the right to life of fetus, from the time it is still in the womb, is the legal basis for dealing with human trafficking. In that way, trading activities, including buying and selling a fetus when it has not yet been born can also be handled administratively or criminally. It helps to prevent human trafficking in the first place, rather than waiting until the child is born. Moreover, when the child is born, it is extremely difficult to detect, handle and collect evidence to prove this kind of crime because the act is done in a second or other third countries. With the dangerous nature and prevalence of fetal trafficking in Viet Nam today, and the disproportionateness of current legal sanctions against this practice, we suggest considering fetal trafficking as a form of human trafficking and it is necessary to criminalize fetal trafficking. Criminal law should recognize fetal as a sign of crime or consider it as an early stage in the criminal process of human trafficking.

In the upcoming time, Viet Nam needs to continue to unify and concretize the issue of the right to life of the fetus in legal documents, so that these regulations will be aimed at protecting, promoting and developing the right to life of the fetus, in line with international common standards in the era of globalization and integration. To effectively tackle this crime and discover the sophisticated tricks used by criminals, the prosecuting agencies need to focus on collecting more evidence other than testimony as well as converting operative information and documents into legal evidence. In addition, countries in the world should have robust international cooperation mechanisms in place - including laws and agreements on extradition and mutual legal assistance - among other legal means to assist in ensuring that evidence is effectively provided across countries for anti-trafficking law enforcement.

\section{REFERENCE}

Alston, P. (1990). The unborn child and abortion under the draft convention on the rights of the child. Human Rights Quartely, 12, 156.

https://doi.org/10.2307/762174

Chornous, Y., Vakulyk, O., Pylypenko, S., Bidniak, H., \& Ostapchuk, A. (2020). Current challenges of international cooperation in the area of human trafficking countering. International Journal of Advanced Science and Technology, 29(8 Special Issue), 2344-2353.

Dang Truong (2008). Fetus trafficking: How is the mother handled?. People's Public Security Newspaper. Recovered from https://cand.com.vn/Phong-su-tu-lieu/Buon-ban-thai-nhiNguoi-me-bi-xu-ly-the-nao-i64013/, 09:24 18/07/2008
De Jesus, L. M. (2011). Revisiting Baby Boy v. United States: Why the IACHR Resolution did not Effectively Undermine the Inter-American System on Human Rights's Protection of the Right to Life from Conception. Fla. J. Int'I L., 23, 221.

Do Duc Minh (2017). The Influences of Social-economic Factors to the Occurance and Development of Transnational Crimes in the Northwest, Science Journal of VNU: Law School. volume 33, no. 1, 50-65, http://repository.law.vnu.edu.vn/ jspui/123456789/1276

Duc, N.T. (2021). A Comparative Study of the Concept of the Child in the UN Convention on the Rights of the Child 1989 and Vietnamese Law. VNU Journal Of Science: Legal Studies, 37(3). doi:10.25073/2588-1167/vnuls.4332

Harris, L. H., \& Paltrow, L. (2003). The status of pregnant women and fetuses in US criminal law. JAMA, 289(13), 1697-1699. https://doi.org/10.1001/jama.289.13.1697

Huntley, S. S. (2013). The Phenomenon of "baby Factories" in Nigeria as a New Trend in Human Trafficking (Vol. 3). International Crimes Database.

Khanh Hoan (2018), Crosing the border to sell children - Breaking blood love in the foreign country, Thanh Nien Newspaper, Recovered from https://thanhnien.vn/vuot-bien-ban-con-ruttinh-mau-mu-o -xu-ngoi-post811784.html

Le, T. H., Carrington, K., Tran, T. H., Nguyen, T. P., Le, T. K., \& Bui, N. H. (2018). Inter-agency cooperation to raise awareness on human trafficking in Viet Nam: Good practices and challenges. Asian journal of criminology, 13(3), 251-274. https://doi.org/10.1007/s11417-018-9269-x

Levchenko, C., Kovalchuk, L., Udalova, O. et al. (2011). SocioPedagogical Bases of Counteracting Human Trafficking and Children Exploitation, Kyiv: "Ukraine" Agency.

Lien Lien (2019). Why is it so difficult to handle buying and selling fetuses?. VTV online newspaper. Recovered from https://vtv.vn/trong-nuoc/mua-ban-bao-thai-vi-sao-kho-xu-ly 20191221203347171.htm, 21/12/2019 21:01 GMT+7

Mason, J. K. (2005). What's in a Name: The Vagaries of Vo $v$ France. Child \& Fam. LQ, 17, 97.

Manson, R., \& Marolt, J. (1987). A new crime, fetal neglect: State intervention to protect the unborn-Protection at what cost. Cal. WL Rev., 24, 161

Minh Tam (2020). Rescuing 3 pregnant women preparing to go abroad to sell fetuses. People's Public Security Newspaper. Recovered from https://cand.com.vn/Ban-tin-113/Giai-cuu-3Phu-nu-mang-thai-chuan-bi-ranuoc-noi-ban-bao-thaii569466/12:27 June 16, 2020

Murray, W. (1989). La nature et les droits du fœtus. Laval théologique et philosophique, 45(2), 209-227. https://doi.org/10.7202/400456ar

Nguyen, Dung \& Le, Toan \& Do, Thanh \& Nguyen, Cuong. (2020). Human Trafficking in Viet Nam: The Issues and Responses of the Vietnamese Government. International Journal of Innovation, Creativity and Change. 13 (7 Issue), 135 - 153.

Nguyen Thao (2019). The startling confession of a mother who sold her fetus for 80 million dong. VietNamNet Newspaper Recovered from https://vietnamnet.vn/vn/doi-song/media/loithu-nhan-giat-minh-cua-nguoi-me-ban-bao-thai-lay-80-trieudong-563328.html

Parisot, T. (2002). Sur la piste de l'esclavage moderne. Manière de voir, (3), 025-025. https://doi.org/10.1088/1126-6708/2002/12/025

Plomer, A. (2005). A foetal right to life? The case of Vo France. Human Rights Law Review, 5(2), 311-338. https://doi.org/10.1093/hrlr/ngi017

Pryimachenko, D., Ivanskyy, A., Lipynskyi, V., Matvieiev, O., \& Povoroznik, A. (2021). Counteracting illegal border crossing and human trafficking: comparative analysis. Amazonia Investiga, 10(42), 196-205.

https://doi.org/10.34069/Al/2021.42.06.18 
Quoc Nam, Thai Loc, Nghi Xuan (2020). Selling the fetus - unending pain - Part 1: Selling the fetus from the womb. Tuoi Tre Online. Recovered from https://tuoitre.vn/ban- thai-nhi-noidau-chua-co-hoi-ket-ky-1-ban-con-tu-trong-bung-me2020052421501008.htm25/05/2020 06:04 GMT+7

Quoc Nam, Thai Loc, Nghi Xuan (2020). Selling the fetus - unending pain - Part 2: Ghostly hands. Tuoi Tre Online. Recovered from https://tuoitre.vn/ban-thai- Nhi-noi-dau-chua-co-hoi-ketky-2-nhung-ban-tay-ma-quai-20200526091124684.htm, May 26, 2020 09:51 GMT+7

Quoc Nam, Thai Loc, Nghi Xuan (2020), Selling the fetus - unending pain - Final period: Need to cut off fetus trafficking, Tuoi Tre Online. Recovered from https://tuoitre.vn/ban -thai-nii-noidau-chua-co-hoi-ket-ky-cuoi-can-chat-dut-nan-buon-bao-thai20200527084107545.htm, May 27, 2020 13:12 GMT+7

Steering Committee 138/CP (2015). Final report on the National Plan of Action against Human Trafficking, period 2011-2015 (No. 439/BC-BCD).

Thien Thanh (2019), "The pain of buying and selling fetuses across the border", People's Public Security Newspaper, https://cand.com.vn/Ho-so-Interpol/Nhuc-nhoi-mua-ban-baothai-qua-bien-gioi-i545672/, 08:01 03/12/2019
Tran, L. (2017). Receiving the Provisions of the Federal Republic of Germany's Criminal Law to Prevent Abortion for Gender Reason by Criminal Law in Viet Nam. VNU Journal Of Science: Legal Studies, 33(1). https://js.vnu.edu.vn/LS/ article/view/4060

Udasmoro, W. (2003). Les lois et la politique de l'avortement en Indonésie: un dilemme pour les femmes?. Archipel, 65(1), 43-54. https://doi.org/10.3406/arch.2003.3749

Vũ, T. G. (2017). Cross-border migration of ethnic minorities in the Northwest region. Viet Nam Journal of Social Sciences, 4 40-48.

Winterdyk, J., \& Reichel, P. (2010). Introduction to Special Issue: Human Trafficking: Issues and Perspectives. European Journal of Criminology, 7(1), 5-10. https://doi.org/10.1177/1477370809347894

Zimmerman, C., Yun, K., Shvab, I., Watts, C., Trappolin, L., Treppete, M., ... \& Regan, L. (2003). The health risks and consequences of trafficking in women and adolescents: Findings from a European study. London School of Hygiene \& Tropical Medicine.

Received on 20-10-2021

Accepted on 13-12-2021

Published on 23-12-2021

https://doi.org/10.6000/1929-4409.2021.10.182

(C) 2021 Thuy et al.; Licensee Lifescience Global.

This is an open access article licensed under the terms of the Creative Commons Attribution License (http://creativecommons.org/licenses/by/4.0/) which permits unrestricted use, distribution and reproduction in any medium, provided the work is properly cited. 